\title{
Students Difficulties in Determining Case in Sentence
}

Ruly Adha ${ }^{1 凶}$, Syifa Nishrina ${ }^{2}$

${ }^{1}$ English Education Department, Institut Agama Islam Negeri Langsa, Aceh, Indonesia

${ }^{2}$ English Education Department, Institut Agama Islam Negeri Langsa, Aceh, Indonesia

email: adharuly@yahoo.com

Received:

May 22, 2021

Revised:

June 15, 2021

Accepted:

June 29, 2021

\section{ABSTRACT}

The objectives of this research were to find out the students difficulties in determining types of case and to investigate the reasons why the students had difficulties in determining case. This was a qualitative descriptive research. The subject of this research was the sixth semester students of English Department in IAIN Langsa that consist of 30 students. Documentation, questionnaire and interview were the instruments in collecting the data. Based on the data, the students felt difficult in determining types of case such as accusative, locative, nominative, possessive, agentive, and ablative. It can be seen from the mistakes made by students through documentation and supported by the results obtained from questionnaire and interview. Then, there were several reasons why the students had difficulties in determining case. They were: 1) Many types of case given by a lecturer made the students difficult to remember them. 2) The students were confused with the types of case because a noun phrase can have more than one type. 3) The students felt difficult to distinguish between accusative and dative case. 4) The students did not master English grammar well.

Keywords: Case; Grammar; Noun Phrase

\section{INTRODUCTION}

Language is systematic which means that language consist of the element of sound, word, and sentence. Each element is studied in different disciplines. Phonology is the study of sound; morphology is the study of word; and syntax is the study of sentence. Phonology, morphology, and syntax are called grammar of language. Chomsky (in Radford, 1988:3) states that "a grammar is a model (=systematic description) of those linguistic abilities of native speakers of a language which enable them to speak and understand their language fluently". It can be concluded that language consists of a set of rules which is known as grammar.

In Indonesia, grammar is a subject taught in the high school until university level. In grammar, a teacher will teach students about the rules in making sentences. Of course, for students who learn a foreign language, especially English, it will be difficult in understanding grammar because the students must remember and follow the rules when they want to construct English sentence. It makes grammar become a difficult subject. One of materials that was taught in grammar is case. Case is the function or the role of noun phrase in a sentence. 
Moreover, Aswad (2016:176) divides case into five types as follows:

a. Nominative case

Nominative case is a noun phrase that functions as a subject of a sentence which locates at the beginning of a sentence, for example 'She sang a song'. 'She' is a nominative case.

b. Possessive case

Possessive case is a noun phrase that indicates a possession, for example 'This is my book'. 'my book' is a possessive case.

c. Objective case (accusative case)

Objective case is a noun phrase that functions as a direct object of a verb, for example 'He drove his car'. 'his car' is an objective case.

d. Dative case

Dative case is a noun phrase that functions as an indirect object of a verb, for example 'She gave Mary a novel'. 'Mary' is a dative case.

e. Vocative case

Vocative case is a noun phrase that functions as an address, for example 'John, where will you go?' 'John' is a vocative case.

Meanwhile, Teresa (1997:10-15) says that case consists of six types, namely nominative, accusative, dative, genitive, instrumental, and vocative. Nominative, accusative, dative, and vocative are similar with Aswad's case. Genitive case is a noun phrase that expresses quantity such as 'some' or 'any'. Instrumental case is a noun phrase that functions as an instrument or a tool used by a subject.

However, Jumino (2012:15-16) states that case consists of ten types as follows:

a. Nominative case

Nominative Case is a noun phrase that shows a subject in a sentence. Subject is the person or the thing who or which carries out the action of the verb in the sentence, for example 'They always come late'.

b. Accusative case

Accusative case is a noun phrase that functions as a direct object in a sentence, for example 'He bought a ball'.

c. Dative case

Dative case is a noun phrase that functions as an indirect object in a sentence, for example 'My mother made me a cake'.

d. Possessive case

Possessive case is a noun phrase that shows possession in a sentence, for example 'The man arrived at my brother's house'.

e. Ablative case

Ablative case is a noun phrase that functions as an instrument or a tool used by the subject, for example 'People go to the mountain on horse'.

f. Vocative case

Vocative case is a noun phrase that functions to address someone in a sentence, for example 'I forgot to bring my book, Sir!'

g. Appositive case 
Appositive case is a noun pharse that functions to give additional information in a sentence, for example 'Mr. John, our new teacher, is my uncle'.

h. Locative case

Locative case is noun phrase that functions to shows place in a sentence, for example 'They bought the pens in the store'.

i. Benefactive case

Benefactive case is a noun phrase that shows someone or something get benefit from the subject, for example 'She baked a cake for her daughter'.

j. Agentive case

Agentive case is a noun phrase that functions as an agent or a doer in a sentence, for example 'The book was written by Gary'.

Another example, in the sentence 'I buy the map in the shop' consists of three noun phrases, namely ' $I$ ', 'the map', and 'the shop'. Although they are all noun phrases, those noun phrases have different types of case because of their positions (functions or roles) in the sentence. 'I' is a nominative case because it functions as the subject of the sentence; 'the map' is an accusative case because it functions as the direct object of the verb 'buy'; and 'the shop' is a locative case because it functions as the adverb of place.

In grammar, the students are expected to understand the function or the role of noun phrase in a sentence so that they can easily understand a sentence and can construct a good sentence. However, in fact, the students feel difficult in determining case contained in a sentence. They are usually wrong and confused in determining the types of case in a sentence and they cannot remember the types of case in a sentence. The cause is that the students do not understand the grammatical structure of a sentence. For example, the students do not know what the object (indirect or direct) is. So, when the students cannot determine whether it is indirect or direct object, they will be difficult in determining the types of case in a sentence. Therefore, this research was conducted in order to find out the students difficulties in determining types of case and to investigate the reasons why the students had difficulties in determining case.

\section{METHOD}

This research was a qualitative descriptive research. According to Sugiyono (2016:9), a qualitative research is used to examine the condition of natural objects where the researchers are the key instruments. This research described the results of the study according to what happened in the field without manipulation. Qualitative descriptive research is a study that describes the subject and object of research based on the facts in the field and the data obtained are words, not numbers. The research was conducted in IAIN Langsa on Jln. Meurandeh, Kota Langsa, Provinsi Aceh. The subject of the research was the sixth semester students in English Department, IAIN Langsa which consisted of 30 students. The instruments used in this research were documentation, questionnaire, and interview. The researchers applied written interview. The researchers interviewed the students who had been taught case. The 
researchers chose close-ended questionnaire. Close-ended questionnaire provides some answers and the respondents only choose one of the answers. It includes multiple choice, dichotomous (only two choices, usually yes/no) or a scale (questions where the choices are ranked) (Arikunto, 2006:183). The researchers provided several statements and the students must fill the checklist of the questionnaire. The questionnaire was distributed to the sixth semester students at English Department, IAIN Langsa, as the subject of the research. Interview and questionnaire were used to answer the reasons why the students had difficulties in determining case. The researchers used documentation in this research. Documentation is a record of events that have passed. Documents can be in the form of writing, images, or monumental works from someone. Documents in the form of writing, for example, diaries, history of life (life history), stories, biographies, regulations, policies. Document study is a complement to the use of observation and interview methods in qualitative research (Sugiyono, 2016). This documentation is used to support the data needed. The documentation in this research was the result of a test about case given by a lecturer. The documentation was used to answer the students difficulties in determining types of case. In this reserach, the researchers used Miles \& Hubberman data analysis techniques. Miles and Hubberman argue that the activity in qualitative data analysis is done interactively and continuously until complete so that the data is saturated. Activity in data analysis, is data reduction, display, and conclusion drawing/verification (Sugiyono, 2016:246).

Picture 1: the step in analyzing

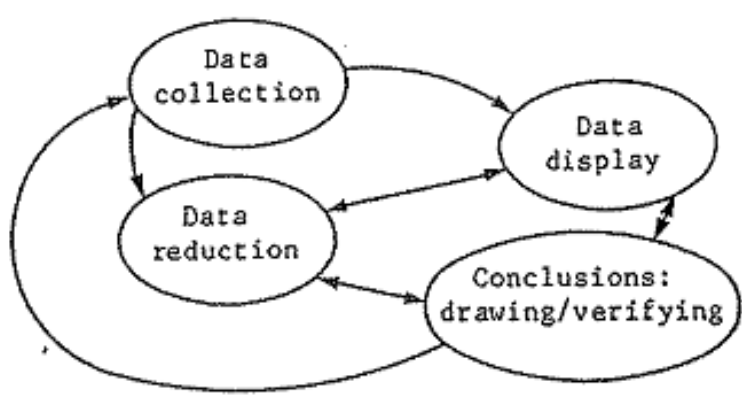

Data analysis: Interactive model by Miles and Hubberman (1994:26)

\section{Data Reduction}

Reducing data means summarizing, choosing the things that focus on the important things, sought the theme and pattern. Thus, the reduced data will provide a clearer picture and make it easier for researchers to perform further data collection and seek when needed.

\section{Display Data}

After the data is reduced then the next step is to display data. In qualitative studies, the presentation of data can be presented in brief descriptions, relationships between categories. The most commonly used for the presentation of qualitative data is with narrative text. By displaying data, it is easier to understand what is happening and to plan the next work based on what is understood. 


\section{Drawing Conclusion / verification}

The third step is the conclusion and verification. The initial conclusion is still temporary and will change if no strong evidence is found to be available at the next data collection stage. But if the conclusions in the early stages are supported by valid and consistent evidence when the researcher returns to the field to populate the data, then the conclusion presented is a credible conclusion.

\section{FINDINGS AND DISCUSSION}

\section{Students Difficulties in Determining Types of Case}

The data were obtained from the documentation. The documentation was the result of test about case given by a lecturer. The results were as follows:

\section{a. Accusative case}

Some students were difficult in analysing the accusative case. The first mistake was in analysing the sentence in question number 2 'Some scholars from Indonesia and abroad investigated the degree of acidity'. In this question, seven students, student number 7, 9, 15, 23, 24, 27, and 29, gave the wrong answer. Student number 7, 23, 24, 27 and 29 answered the noun phrase 'the degree of acidity' as an appositive case. The correct answer should be an accusative case. Student number 9 and 15 cannot answer it. In question number 4 'Descriptive study focuses on the description of social phenomenon', two students, student number 7 and 28 , gave the wrong answer. Students number 7 and 28 answered the noun phrase 'the description of social phenomenon' as an appositive case. The correct answer should be an accusative case. In question number 5 'The research analyses the implementation of corrective feedback', six students, student number 9, 17, 23, 24, 27, and 29, gave the wrong answer. Student number 9 answered the noun phrase 'the implementation of corrective feedback' as a direct object. However, the correct answer was an accusative case. Student number 17 answered the noun phrase 'the implementation of corrective feedback' as a benefactive case. Meanwhile, student number 23, 24, 27 and 29 answered it as an appositive case. In question number 6 'The handsome boy made her his girlfriend', twenty-two students, student number $1,2,3,4,5,6,7,8,9,10,11,12$, $13,14,15,23,24,26,27,28,29,30$ gave the wrong answer. Most students answered the noun phrase 'her' as a dative case. The correct answer should be an accusative case. While, student number 23, 24 and 27 did not answer it. In question number 7 'I have met Alex, the best employee of the year', only student number 15 gave the wrong answer. The student answered the noun phrase 'Alex' as an agentive case. However, the correct answer was an accusative case. From the results of questionnaire and interview, most students answered "sulit dalam menentukan kata benda yang berperan sebagai direct object di dalam sebuah kalimat" (it was difficult in determining noun phrases that function as a direct object in sentence). They cannot distinguish between direct and indirect object. 


\section{b. Locative case}

Some students were difficult in analysing the locative case. In question number 2 'Some scholars from Indonesia and abroad investigated the degree of acidity', twenty-three students, student number $1,2,3,4,5,6,9,10,11,12,13,14,15,16,17$, $18,19,20,21,25,26,28$ and 30 gave the wrong answer. They answered the noun phrase 'from Indonesia and abroad' as a nominative case. However, the correct answer should be a locative case. In question number 8 'The girl writing her daily activities in the diary with some colorful pens', student number 15 gave the wrong answer. The student answered the phrase 'in the diary' as an ablative case. The correct answer should be a locative case. In question number 9 'He was sitting under the tree', student number 23 gave the wrong answer. Student number 23 answered the phrase 'under the tree' as a possessive case. The correct answer should be a locative case. From the results of questionnaire and interview, the students said, "saya sulit dalam menentukan kata benda yang menunjukkan sebagai lokasi, tempat kejadiannya suatu perkara di dalam sebuah kalimat" (it was difficult in determining noun phrases that show the location or the place).

\section{c. Nominative case}

In questions number 1 'The data were collected by observers in $\mathbf{X}$ and XII classes', student number 29 gave the wrong answer. The student answered the noun phrase 'the data' as an accusative case. The correct answer should be a nominative case because the function of the noun phrase was as the subject in the sentence. In question number 2 'Some scholars from Indonesia and abroad investigated the degree of acidity', student number 6 and 22 gave the wrong answer. The students answered the noun phrase 'Some scholars from Indonesia and abroad' as an agentive case. However, the noun phrase 'Some scholars from Indonesia and abroad' should be analyzed separately, the noun phrase 'some scholar' is a nominative case and the noun phrase 'from Indonesia and abroad' is a locative case. In question number 5 'The research analyzes the implementation of corrective feedback', student number 17 gave the wrong answer. Student number 17 answered the noun phrase 'the research' as an ablative case. The correct answer should be a nominative case. In question number 10 'Romeo and Juliet was written by William Shakespeare, the greatest dramatist', student number 23 answered the noun phrase 'Romeo and Juliet' as the vocative case. However, the correct answer should be a nominative case. From the results of questionnaire and interview, most students said, "saya sulit dalam menentukan kata benda yang berperan sebagai sebagai subject di dalam sebuah kalimat" (it was difficult in determining noun phrases that function as a subject in a sentence).

\section{d. Possessive case}

In question number 6 'The handsome boy made her his girlfriend', six students, student number $8,10,11,12,15$ and 26, gave the wrong answer. The students answered the noun phrase 'his girlfriend' as an accusative case. The correct answer should be a possessive case because the noun phrase showed a possession. From the 
results of questionnaire and interview, the students said, "saya sulit dalam menentukan kata benda yang berperan untuk menunjukkan kepemilikan (possession) di dalam suatu kalimat" (it was difficult in determining the noun phrases that function to show the ownership).

\section{e. Agentive case}

In questions number 1 'The data were collected by the observer in $\mathrm{X}$ and XII classes', student number 28 and 30 gave the wrong answer. The student could not answer the type of case in the noun phrase 'by the observer'. The answer to the noun phrase 'by the observer' should be an agentive case because the noun phrase plays showed the doer in the sentence. From the results of questionnaire and interview, the students said, "saya sulit dalam menentukan kata benda yang berperan sebagai pelaku di dalam sebuah kalimat" (it was difficult in determining noun phrases that function as the doer in a sentence).

\section{f. Ablative case}

In question number 8 'The girl writes her daily activities in the diary with some colorful pens', student number 15 gave the wrong answer. The student answered the noun phrase 'with some colorful pens' as an appositive case. The correct answer was an ablative case because the function of the noun phrase was to show the instrument used by the subject. From the results of questionnaire and interview, the student said, "saya sulit dalam menentukan kata benda yang berperan sebagai alat atau instrument di dalam sebuah kalimat" (it was difficult in determining noun phrases that function as a tool or instrument in a sentence).

\section{The reasons why the students had difficulties in determining case}

After finding the students difficulties in determining the types of case, the researchers analysed the reasons why the students had difficulties in analyzing a case. The researchers gave a closed questionnaire to the students. The students only answered 'yes' or 'no' to each question. The researchers also interviewed the students. Most students answered as follows:

a. sulit membedakan antara peran kata benda sebagai direct object dengan peran kata benda sebagai indirect object dalam sebuah kalimat. (it was difficult to distinguish noun phrases that function as a direct object and an indirect object in a sentence)

b. sulit mengingat kesepuluh case yang di berikan oleh dosen. (it was difficult to remember ten types of case given by the lecturer)

c. kurang paham mengenai tata bahasa dalam bahasa inggris. (they did not understand English grammar)

d. terkadang bingung dalam menyebutkan nama-nama dari masing-masing case. (the types of case made the students confused)

From the results of questionnaire and interview, the researchers analysed the reasons why the students had difficulties in determining case. The reasons were as follows: 
a. Many types of case given by a lecturer made the students difficult to remember them. The students must be able to remember the types cases that had been given by the lecturer.

b. The students were confused with the types of case because a noun phrase can have more than one type based on its role in a sentence, for example 'He drove his car'. 'his car' can be an accusative case and a possessive case based on different point of view. It can be accusative because it plays a role of a direct object of the verb 'drove' and it also can be possessive because it shows possession.

c. The students felt difficult to distinguish between accusative case and dative case. A sentence can have two objects, direct and indirect object. Accusative case is a noun phrase that functions as a direct object. Dative case is a noun phrase that function as an indirect object.

The students did not master English grammar well. When the students analysed a sentence, the students did not know the functions of noun phrase in the sentence. So, it made the students difficult in determining the types case contained in the sentence.

\section{CONCLUSION}

After conducting the research, the researchers concluded that the students feel difficult in determining accusative case, locative case, nominative case, possessive case, agentive case and ablative case. The reasons why the students had difficulties in analyzing case in grammar were as follows: 1) Many types of case given by a lecturer made the students difficult to remember them. 2) The students were confused with the types of case because a noun phrase can have more than one type based on its role in a sentence. 3) The students felt difficult to distinguish between accusative case and dative case. 4) The students did not master English grammar well.

\section{REFERENCES}

Arikunto, Suharsimi. (2006). Prosedur Penelitian \& Pendekatan Penellitian. Jakarta: Rineka Cipta.

Aswad, Muhammad. (2016). English Grammar. Yogyakarta: Deepublish.

Coghil, Jeffrey and Stacy Magendanz. (2003). English Grammar. New York: Wiley Publishing.

Cook, Walter Anthony. (1922). Case Grammar Theory. Washington DC: Georgetown University Press.

Dahm-Draksic, Teresa. (1997). A Role and Reference Grammar Analysis of CaseMarketing In Croatian. Oxford: Oxford University Press.

Lyons, John. (1968). Introduction to Theoretical Linguistic. London: Cambridge University Press. 
Miles \& Huberman. (1994). Qualitative Data Analysis-An Expanded Sourcebook. New Delhi: Sage Publication.

Moeleong, Lexy. (2002). Metodologi Penelitian Kualitatif. Bandung: Remaja Rosdakarya.

Radford, Andrew. (1988). Transformational Grammar: A First Course. London: Cambridge University Press.

Seppo Kittila, et.al. (2011). Case, Animacy and Semantic Roles. Amsterdam: John Benjamin Publishing Company.

Sugiyono. (2013). Metode Penelitian Kuantitatif Kualitatif dan R\&D. Bandung: Alfabeta.

Suhadi, Jumino. (2012). Course of English Structure. Medan: Fakultas Sastra UISU.

Swan, Michael. (2005). Practical English Usage Third Edition. New York: Oxford University Press.

Vickie, A. Lambert \& Clinton E. Lambert. (2012). Qualitative Descriptive Research: An Acceptable Design. Pacific RIM International Journal. 